\title{
Moose Anecdote
}

\section{By NELLIE CAMERON, COXWORTH, Davidson}

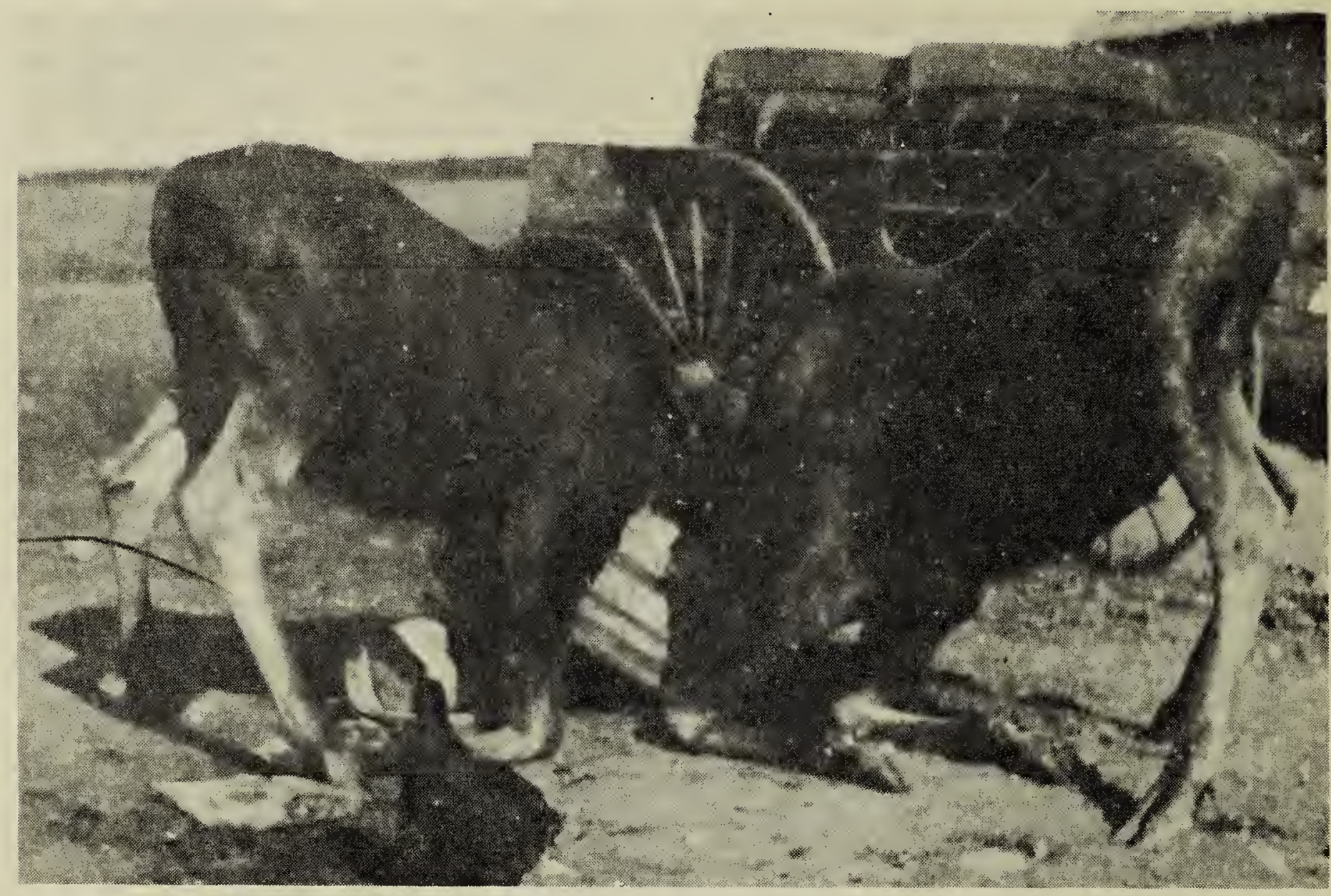

One year my Father succumbed to the urge of adventure, and set out with my two brothers to capture some small deer. He satisfied his sense of Justice and reason, by carefully explaining to my Mother that he had seen where Algonquin Park Officials were desirous of restocking the park with deer and moose.

They made a trek into the foothills of the Riding Mountain. It was real deer country, thick with spruce and with beautiful Clear Lake lying in the centre.

Lady Luck must have ridden right along with my Dad for the first evening they made camp by a small lake they spotted a large cow moose feeding in the rushes at the water's edge. Father with a warning to the boys to keep an eye on it, strolled out through the low prairie bushes, with a small rope tied in two loops, just in case. Looking down as he walked he almost stepped on two small moose calves snuggled close to each other. With a hasty glance at Mrs. Moose, he knelt, slipped the loops, one over each head, picked the twins up, one under each arm, and started back for the wagon.
Fortunately for him the small fry made no sound, and he reached camp without mishap.

Father had come prepared, and that evening they fed the baby moose with warm milk. (Their cry is very much like that of a small child a sort of plaintive whine.)

In a couple of days, two more calves and one beautiful little elk, had been found. So Father and his two "right hand men," returned home late one night.

I well remember my big brother walking into the house and with a very casual air asking us if we would heat a little milk for him. Not to be fooled this way, we sprang at him with eager questions, to all of which he declared "they" had five "youngsters" out in the barn, and he had come for some warm milk for them.

We refused to believe him, but finally my Mother yielded, prepared the milk and we all trouped after him to the barn. There, sure enough, in the dim light of the front stall lay two strange little animals on a bed of straw. They looked stranger still when they stood up on long wobbly legs. But what captivated us 
completely was the small elk, fawn colored with white spots. When she stood up her whole body seemed on invisible springs. Her eyes looked out friendly and trusting and her ears pricked back and forth. We loved her from the start and called her "Gentle."

In the second stall were two more small moose making up our adopted family.

At first we fed them from a bottle, then gradually weaned them to a large pan, from which they all drank at once. They soon became as tame as calves, but wandered farther afield as time went on.

In the evening when it was feeding time, my father would walk around the yard, and to the edge of our small bluff, calling them by name, "Come Gentle! Come Major! Come Ivan!" Soon we would hear them crashing through the young poplars. The moose with lumbering awkward gait would lope into the yard accompanied by Miss Gentle, who came springing over the grass, head high, ears at the alert and dainty feet scarcely tcuching the ground.

It was a piece of real strategy, (as well as some athletic prowess), for my father to get to the pan first, pour out the milk and leap aside, before all five flopped down on their knees, in a circle, heads in the pan, rumps high in the air, as in the above picture. It was quite a sight!

They were a real attraction to the whole neighborhood, especially to the children. I recall, one day, at the "little red schoolhouse" the pupils rising spasmodically from their seats, pointing through the window, crying out with fine disregard for the English language "Oh look! look! Camrun's Deers!"

They were spellbound at the way the moose could lift and bend their long legs to step over a fence with "the greatest of ease."

As they grew older they wandered farther. They sometimes stayed away for as long as two or three days but would, eventually, come home. When the moose were fully grown my father sold them to Algonquin Park where, perhaps today, some of their descendants stand and gaze, looking off into the "Far Distance."

It is a debatable point (in justice) whether to capture and place in pro- tected areas these interesting and lovable wild animals or whether to leave them in their natural state, where some day the hunter's gun will lay the proud monarch of the woods low.

\section{NATURE $1904-1955$}

(Continued from Page 15)

Winters were so long, everyone eagerly listened for the first bubbling song of the Meadowlark, followed by the haunting sweet music of the Song Sparrcw, and the soft chucklings of the Sharp-tailed Grouse on the dancing grounds. This is another sound we miss, for very few Sharptails are seen here now.

We now see species of birds, new to our locality, not having seen them until our province became well settled. These are Bluebirds, Brown Thrashers, Black-billed C u c k o o s, Wood Thrushes - mostly residents of treed areas. One bird we have not been able to identify was a constant annoyance during haying time. When we were helping dad with the hay around marshy sloughs, these slate grey birds, similar in shape to a gull, would dive swiftly down, dangerously close to our heads with harsh cries of "Flick it", continuing this till we left - doubtless defending their nests. Will someone tell us what these are please?

In closing we would like to appeal to parents to interest their children in protecting our birds and wild flowers. We hope that future generations will fully realize the enjoyment to be gained by nature observations.

\section{Flooded Out - But Survived}

(Continued from Page 19)

- all nine of them. We lifted the sticks and leaves down to the original nest, put them in a pail and did some counting. The duck had placed about one-half gallon of leaves and more than nine hundred sticks under the eggs.

I have asked several people if they thought the drake did anything to help carry sticks or leaves or take a turn at keeping the eggs warm. No one, so far, will give him credit for anything. They consider him just a handsome no good husband. What do you think? 